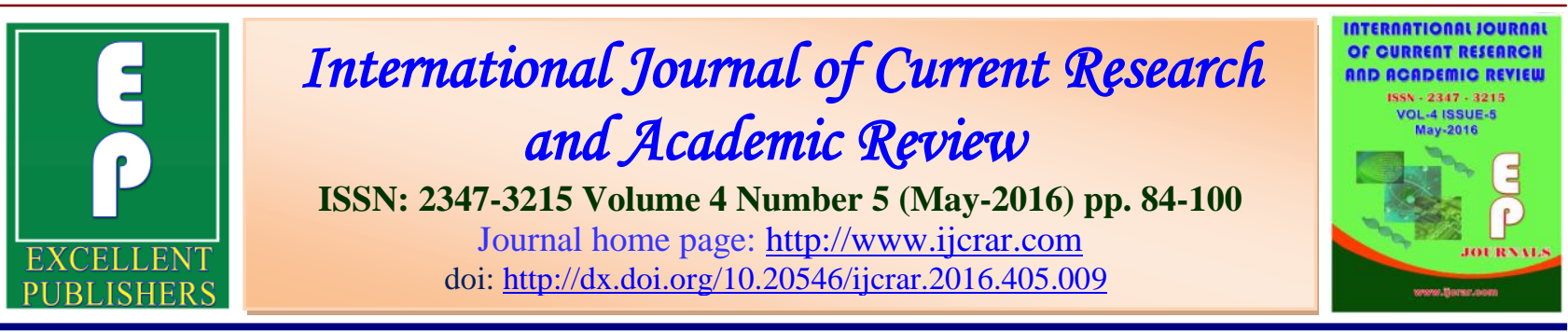

\title{
Socio-Economic Status of the Fish Curers of the Dry Fish Industry of the Coastal Areas of West Bengal, India
}

\author{
Chanchal Samanta $^{1}$, Utpal Bhaumik ${ }^{2}$ and Bidhan Chandra Patra ${ }^{1}$ \\ ${ }^{1}$ Department of Aquaculture Management and Technology, Vidyasagar University, \\ Medinipore- 721102, West Bengal, India \\ ${ }^{2}$ Former Divisional Head, Central Inland Fisheries Research Institute, Barrackpore, Kolkata- \\ 700120, West Bengal, India
}

*Corresponding author

\begin{tabular}{|c|c|}
\hline KEYWORDS & A B $\mathbf{S} T \mathbf{T} A \mathbf{C} \mathbf{T}$ \\
\hline $\begin{array}{l}\text { Dry fish, } \\
\text { Socio-economic, } \\
\text { Social milieu, } \\
\text { Middle man, } \\
\text { Raw material, } \\
\text { End product }\end{array}$ & $\begin{array}{l}\text { Fish curing is an important and age old method of fish preservation in India } \\
\text { and major part of marine landings is still converted into cure products mostly } \\
\text { dry fish. Dried fish continues to enjoy a steady market West Bengal, India, } \\
\text { particularly among the low income group on account of its low cost of } \\
\text { production, extended shelf life at ambient temperature, convenience of } \\
\text { packaging and transport. The dry fish curers are, by and large, economically } \\
\text { backward and socially at lower strata of the Society, despite of their unstained } \\
\text { efforts, dexterity and skill; their earnings on the whole are at still at lower } \\
\text { level when compared with other industrial and professional workers. An } \\
\text { investigation was carried out to unravel the socio-economic status of the fish } \\
\text { curers involved in the dry fish industry of the coastal belts of West Bengal, } \\
\text { India. Generally for undertaking fish drying activity, the fish curers procure } \\
\text { raw materials varying between } 10,000 \text { and } 70,000 \text { kg/annum. The end } \\
\text { product (dry fish) turns approximately to } 1 / 3 \text { to } 1 / 4 \text { from the raw material } \\
\text { (fresh fish). The study indicates that sizeable active fish curers belong to the } \\
\text { age group of } 35-55 \text { years. The curers of the sample are mostly Jalia } \\
\text { Kaibarttas by caste which belongs to Scheduled Cast (SC) community. It } \\
\text { reveals that the primary occupation of most of the fish curers is fish } \\
\text { preservation. During drying season, fish curers earn between INR } 6000 \text { to } \\
8000 \text { per month on an average. On account of their poverty and social } \\
\text { status, they are forced to depend on middlemen. In order to overcome } \\
\text { this, however, communities must be empowered to make decisions locally } \\
\text { and to take actions that meet local opportunities and problems. }\end{array}$ \\
\hline
\end{tabular}




\section{Introduction}

Fish constitutes an important component in the regular diet of the populace of West Bengal, India. Here, about $78 \%$ of fish catch is consumed in fresh form, $6 \%$ is used as dry fish and rest is used as frozen fish. Over the years it has become a resource giving employment to a large section of society called fishers, middlemen in fish trade, processors and exporters. Presently fish also plays a pivotal role in the export earnings of many Asian countries. Fisheries have also social, economic, nutritional and food security importance. It is roughly estimated that over 40 million people are today employed worldwide in the primary fish production activities (FAO, 2012). Indian dry fish export contributes $8 \%$ of all form of fish exports and earned INR 7540 million during 2012-2013 (MPEDA, 2013). The nutritional quality of dried fish remains unchanged, sometimes retains higher quality standards compared to fresh fish (Faruque, et al., 2012).

Fish curing is an important and age old method of fish preservation in our country and major part of marine landings is still converted into cure products mostly dry fish (Balasubramaniam and Kaul, 1982). About $2 / 3$ of the total landed fish in India are consumed in the fresh condition and remaining is utilized by preservation in other methods (Govindan 1985). A large quantity of fish captured during the coastal fishing in winter months generally comprised of low priced fishes and these are procured by the fishers in West Bengal for sun drying (Saha 1970).

The coastal waters of the Bay of Bengal appear to be potentially very rich fishing grounds with a great variety of species. The processing of fish other than freezing is done mainly by the artisanal in this region under small scale operation in remote fishing villages. Salting and drying have been too age-old methods of preserving surplus fish practiced by the fishers. But in many countries of Asia including India, fish curing and drying is in declining trend. Although in West Bengal the consumer preference goes towards consumption of fresh fish but cured products mostly dry fish also have been gaining priority since it has got export market. The improvement of fishery product as in the case of dry fish is an essential requirement if better use is to be made of marine resources. However, dried/ salted fish still continues to enjoy a steady market, particularly among the low-income group on account of its low cost of production, extended shelf life at ambient temperatures, and convenience of packaging and transport. Thus, the fish curing industry has been playing an important role in West Bengal economy through employment generation, enhanced income vis-a-vis socio-economic condition of the fishers/curers and earning valuable foreign exchange. In order to achieve improvement in obtaining quality dry fish, some essential factors are taken into consideration by the fish curers. The fish curers are, by and large, economically backward and socially at lower strata of the Society, despite of their unstained efforts, dexterity and skill; their earnings on the whole are at still at lower level when compared with other industrial and professional workers. Hence, evaluation socio-economic milieu under which fish curers operate, a condition precedent to any worthwhile development strategy, is contemplated for dry fish industry. The objective of the investigation is to unravel the socio-economic status of the fish curers involved in the dry fish industry of the coastal belts of West Bengal, India.

\section{Materials and Methods}

Large numbers of fish curers of the coastal belts of West Bengal, undertake fish drying 
as their profession. The location where fish landing as well as drying activities are undertaken, is locally known as Khuti. An investigation was carried out in such 3 Khuties of the district Purba Medinipore namely Junput, Haripur and Jaldha and in 4 Khuties namely Patharpratima, Baliara, Namkhana \& Kakdwip of the district South24 Parganas to know the socio-economic status of the fish curers. List of the fish curers of two districts was prepared initially and 25 percent of them were selected at random finally which constituted the sample of the study. Thus, a total of 336 fish curers of the sample were personally interviewed with a pre-tested structured schedule developed for this purpose. The Khuti-wise respondents' distribution (Table 1) was; under the district South 24 Parganas, the sample consists of 81 fish curers where Khuti-wise distribution was 50 nos. in Patharpratima, 21 nos. in Baliara, 5 nos. in Durganagar/Namkhana, 5 nos. in Kakdwip Steamer Ghat and under the district Purba Medinipore sample size was 255 nos. where 145 fish curers were from Junput, 80 nos. were from Haripur and 30 nos. from Jaldha.

\section{Results and Discussions}

A large number of varieties of fish species are exploited by the fishers in the coastal regions of South 24-parganas as well as Purba Medinipore districts. Important fishes preferred for human consumption as dry fish or for making fish meal are Harpodon nehereus,Trichiurus savala, Sardinella fimbriata,Cynoglossus semifasciatus, Sardinella longiceps, Pampus argentius, Chirocentrus dorab, Polynemus indicus, Tenualosa ilisha, Rastraliger kanagurta, Thunnus albacores, Euthynnus affinis, Pama pama, Leognathus sp., Setipina phasa, Setipina taty, Scoliodon sp., Barelius bhola and Polynemus paradiseus etc. Samanta et al. (2016), Das et al. (2013), Ghorai et al.
(2014) and Saha (1970) made similar observations.

Generally for undertaking fish drying activity, the fish curers procure raw materials varying between 10,000 and $70,000 \mathrm{~kg}$ /annum. The quantity of procurement of raw material depends mainly upon socio-economic conditions of the fish curers vis-a-vis infrastructure and man power availability. Mostly the procurement starts from 30,000 kg onwards per year. Paul et al., 1997, reported that in the Hooghly estuary, in absolute terms, total quantity of 35,844 tons of fishes was netted out at 282 fishing centres and those were converted to dry fish for sale.

The end product (dry fish) turns approximately to $1 / 3$ to $1 / 4$ from the raw material (fresh fish) as per the study conducted by Samanta et al., 2016 who reported that the end product exhibited approximately $3,000 \mathrm{~kg}$ against $10,000 \mathrm{~kg}$ of raw materials at minimal level and 18,000 $\mathrm{kg}$ against $70,000 \mathrm{~kg}$ of raw materials.

Quality dry fish could be processed only with maximum exposure of sun light and minimum moisture content in the atmosphere. All the fish curers excepting Junput Khuti, availed the same opportunity to get quality dry fish. They undertake the operation of fish drying during November to March. On the other hand in Junput Khuti the entire dry season is divided into two periods as peak and lean. The peak and lean periods for undertaking the dry fish operation largely depends on fishing season only, nevertheless the drying operation culminates with the closing of fishing season by March.

Mostly fish curers mostly function in a group consisting of 3 persons as hired labours. Generally such numbers depend on 
the resource richness of the fish curers vis-avis quantity of raw materials handled for drying. Through in the study it is clear that the hired labours of Namkhana Khuti enjoy the maximum wages on daily basis. The male labours are paid @ Rs. 300/- per day and female labours @ Rs. 250/- per day as the wages for fish drying activity.

The dry fish produced in the area are graded according to quality. The best quality of the product, suitable for human, consumption are graded for export purpose whereas low quality of dry fish like broken, putrefied, containing sands are generally graded for using in the fish meal industry for making poultry/fish feed.

Generally, the quality end product suitable for human consumption is exported to several states of India and as well as to abroad. In India the end product is exported to the states like Assam, Bihar, Uttar Pradesh, Odisha, Tripura, Manipur and North-Eastern states. It is also exported to foreign countries namely Bangladesh, Myanmar, Nepal, China and Pakistan. As such $51 \%$ of the fish curers undertake export of dry fish mostly to Bangladesh through middlemen/traders and fetch good return.

The sector's overall contributions to the economy and creation of livelihoods for rural fisher communities have been phenomenal and with increasing population, the demand for dry fish is also on the rise.

\section{Socio-Personal Status of the fish curers}

The cursory perusal of the Table 2 to 8 under the section indicate the sociopersonal status viz. Age, Caste, Education, Family-size, Occupation and Experience of the fish curers involved in sun drying of the sample consisting of 336 fish curers of the 7 sample sites.

\section{Age Distribution}

The study (Table 2) reveals that the age of the fish curers of the sample varied between 15 and 70 years. Out of 336 respondents, the distribution pattern of age concentrates mostly in between the age 35 and 55 years (72\%) who function as active fish curers and they have been dominating in fish drying process. Frequencies of the age groups have been recorded as per sequence are, 45-50 years $(24.4 \%), 40-45$ years $(19.89 \%), 50-55$ years $(16.64 \%), 35-40$ years $(8.6 \%), 30-35$ years $(7.13 \%), 25-30$ years $(6.8 \%), 55-60$ years $(5.05 \%), 25-30$ years $(3.83 \%), 60-65$ years $(3.55 \%), 15-20$ years $(0.89 \%)$ and 65-70 years $(0.87 \%)$. Thus, the study indicates that sizeable active curers belong to the age group of 35-55 years. Sinha et. al. (2000) while implementing the project on monitoring of inland fisheries component of the World Bank assisted fish and shrimp culture observed average age of the fishers was assessed at 37 years. Bhaumik et al., 2006, while studying socio-economic status of fishers in some beels of West Bengal indicated age group of majority fishers belong to 24 to 26 years. Sugunan and Bhattacharya (2000) mentioned the dominant age group of the fishers engaged in fishing in beels of West Bengal at 30-60 years. Biswas (1991) while studying some socio-economic aspects of fishers of Sundarbans indicated dominant age group of fishers engaged in fishing on estuaries as 2040 years.

\section{Caste Profile}

The curers of the sample are mostly Jalia Kaibarttas by caste which belongs to Scheduled Cast (SC) community. The Jalia Kaibarttas are again divided into two subcastes: Jhalo and Malo. It is fact that unlike aquaculture, profession of fishing/curing has not been accepted by the population of higher castes, of course in this 
investigation some percentage belongs to higher caste. Similar observation have been made by Bhaumik and Pandit (1991), Biswas (1991) and Sugunan et al.,2000, where they also mentioned that the fishermen engaged in beel fishing mostly belong to Scheduled Caste community. Sinha et al., (2000) stated that caste of majority of the fishermen operating under world bank assisted project at Andhra Pradesh, Uttar Pradesh and Behar belong to Scheduled Tribe (56\%) followed by Scheduled Caste (27\%) and Backward Caste (17\%).

After studying the caste profile (Table 3) of the fish curers, it has been observed that out of 336 respondents as many as 148 fish curers belongs the Scheduled Caste (SC) category (44\%), followed by Mahisya (35\%) a group of population belong to higher caste, Muslim (10\%), Other Backward Class $\{\mathrm{OBC}\}(7 \%)$ and Kayastha (3\%). Negligible respondents belong to Brahmin $(0.6 \%)$ and Others Category (0.3\%). Unfortunately, nobody was observed to belong to the Scheduled Tribe (ST) Category in the sample.

Similar observations have been made by Bhaumik and Pandit (1991), Biswas (1991), Sugunan (2000) where they also mentioned that the fishers engaged in fishing activity mostly belong to Scheduled Caste Community. Sinha et al.,2000, stated that the caste of majority fishers operating at Andhra Pradesh, Uttar Pradesh and Bihar belong to Scheduled Tribe (56\%) followed by Scheduled Caste (27\%) and Backward Caste (17\%).

\section{Occupation structure}

Fish-curers are traditionally defined as the persons who irrespective of their castes, pursue fish drying as their chief all respondents was observed (Table $4 \& 5$ ) to be fish drying, but their secondary occupation is fishing, fish-sell, net making and mending and some other activities.

\section{Primary Occupation}

The perusal of the Table 4, reveals that the primary occupation of most of the fish curers $(94 \%)$ of the sample, is fish preservation as fish drying followed by Fishing (4.5\%) as and Net Making and Mending (1.5\%). The study confirms the view made by Bhaumik and Pandit (1991), Biswas (1991), Sugunan and Bhattacharya (2000) who also observed fishing as primary occupation of the fishers.

\section{Secondary Occupation}

The cursory perusal of the Table.5, reveals that the secondary occupation of as many as fish curers $(29 \%)$ Fish sell in other words fish vendor, followed by work as Labourer (26\%), Fishing (22\%), Other activity (16\%) and Net making \& mending as a secondary occupation during off-season is negligible $(7 \%)$.

\section{Education Level}

The present study (Table 6) shows that the fish curers are still educationally backward. As many as $42 \%$ of the respondents of the sample could complete their education at primary level (up to $4^{\text {th }}$ standard) followed by Eight pass (18\%), Illiterate (15\%), Secondary pass $(13.5 \%)$, Can read and write $(10 \%)$ and Graduate fish curers are negligible (1.5\%).

It has been observed that illiteracy has been rampart in the families of the fish curers. Of course, presently children of the fish curers are now sent to school as they are reluctant to involve their children into their profession 
to produce dry fish. But unfortunately they seldom complete the school education due to poverty. Some respondents expressed, sending a child to school involves double expenditure in one hand and the family is deprived of his contribution as labour on the other hand. In the present observation illiteracy has been recorded as $15 \%$ where as Bhaumik and Pandit (1991) observed illiteracy at educational level of the fishers to the maximum extent $(46.10 \%)$ and they also found the similar result in case of primary education of the fish curers. Sugunan and Bhattacharya (2000) observed illiteracy role to the tune of $59 \%$ in the North Bengal and $31 \%$ in South Bengal. Biswas (1991) stated primary education and illiterate education level of fish curers of Sundarbans at $33.67 \%$ and $38.18 \%$ respectively. Shrivastava (1985) reported illiteracy at $88.6 \%$ among the fishers of Eastern part of India. Sinha et al., 2000, observed education level of fishers as mostly illiterate $(42 \%)$, in their study on socioeconomic aspects fishers.

\section{Family Size}

Family is an institution that found in all societies. Generally, it refers to a social unit consisting of a male and female united to each other on a more or less enduring basis for the purpose of mutual emotional support, reproduction of species, socialization and care of progeny and economic co-operation. The perusal of the Table 7 reveals that the family size varies between 2 members and 10 members \& above. Out of 336 respondents of the sample as many as $39 \%$ of the fish curers (130 nos.) are having 4-6 members in their families, followed by 7-9 members $(35 \%), 2-3$ members $(20 \%)$ and $10 \&$ above members $(6 \%)$.

It is interested to note that one family also has been recorded with 10 members. Sugnan and Bhattacharya (2000) observed fishers family having 3-4 members in maximum number $(56 \%)$ in North Bengal. Biswas (1991) indicates 4-6 members in maximum frequency (62.73) in the fishers' community of Sundarbans. Bhaumik and Pandit (1991) mention the majority of fishers family have 4-6 members (56.38\%). Who are engaged in operation in beels of West Bengal, whereas in the present study 4-6 members found in $39 \%$ of the families of the fishers.

\section{Experience}

The study (Table 8) reveals that most of the respondents of the sample are having experience in fish drying for their livelihood between 6 years and 20 years (78\%) whereas 21 to 30 years of experience is possessed by only 38 fish curers (11\%) followed by 1 to 5 years of experience $(8 \%)$ and experience of 31 to 40 years $(3 \%)$.

Families of the fish curers belong to a primary economic group as it is also a basis production unit. Adult males sometimes participate in fishing activities for sustenance of livelihood of their family. It is observed in the present study that most of the fish curers possess reach experience in fish drying method which varies from 1 to 40 years. Bhaumik and Pandit (1991) observed the experience 21 of years as maximum (47.7\%) whereas Biswas (1991) observed 19 to 20 years maximum in Sundarbans.

\section{Wealth status of the Fish Curers}

The wealth status of the respondents has been measured with the help of some components which consists of possession of house and materials like gadgets and other essential tools. In the present study, it can be inferred that economic status of most of the respondents belongs to medium category. 


\section{House in possession of the Fish Curers}

The perusal of the Table 9, reveals that out of 336 respondents of the sample, maximum number of fish curers have house with Tin or Tile shed $(60 \%)$ followed by Pucca (building) house (32\%) and rest 28 fish curers $(08 \%)$ dwell in Thatched hut. This corresponds to the studies made by Bhaumik et al., 1990 and Biswas (1991). Sinha et al., 2000 , revealed that $92 \%$ of the fishers have clay houses and rest have pucca houses in Andhra Pradesh, Uttar Pradesh and Bihar.

\section{Gadgets in possession of the Fish curers}

The study (Table 10) indicates that all the respondents have using several types of gadgets namely Radio set, Wrist watch, Television set, Mobile set, Bi-cycle and Motor- cycle. Out of the 336 respondents, 288 fish curers $(86 \%)$ possess minimum one Bi-cycle, 192 fish curers $(57 \%)$ possess one Television set in their houses. As many as 130 fish curers (39\%) possess one Motorcycle, 108 fish curers (32\%) possess one Radio set where as 49 fish curers (15\%) use Wrist watch. It has been indicated by the respondents that possession of a motor cycle promotes their prestige in the community.

\section{Income of the fish curers}

The present study (Table $11 \& 12$ ) narrates that income of the fish curers become high during season (November to March) but during off-season (April to July) the resource poor fish curers switch on to alternative employment for the sustenance of livelihood, of course they store some quantity of dry fish for selling during offseason.

\section{During season}

The study (Table 11) reveals that out of 336 respondents of the sample, cent percent of the respondents expressed that sun drying of fish largely depends on the caprices of nature. The fish curers earn more income per month through sun drying activity vis-à-vis selling of the product during the season of sun drying of fish (November to March) as compared to off season (April to July). During sun drying season fish curers earned between INR 6000 to 8000 per month on an average by 114 respondents (34\%), followed by 63 respondents (19\%) who earned INR 5000 to 6000,53 respondents $(16 \%)$ earned INR 8000 to $10,000,45$ respondents $(13 \%)$ earned INR 4000 to 5000, 31 respondents (9\%) earned the minimum amount of INR 3000 to 4000 and 30 respondents (9\%) earned the maximum amount of INR 10,000 $\&$ above on an average per month.

\section{During off-season}

The study (Table 12) reveals that off-season (April to July) as many as 83 respondents (25\%) earned INR 4000/- to 4500 per month on an average, followed by INR 3500/- to Rs. 4000/- per month earned by 77 respondents (23\%), INR 4500 to 5000 per month earned by 54 respondents (16\%), INR Rs. 3000/- to Rs. 3500/- per month earned by 48 respondents (14\%), INR 2000 to 3000 per month earned by 46 respondents (14\%) and rest 28 respondents $(8 \%)$ earned INR 5000 and above on an average per month.

\section{Status of Dry fish industry}

It has been observed that fish drying operation is conducted by respondents in open air in the nearest beach. As such they do not use any sophisticated infrastructure for fish drying purpose. Most of the fish curers (58\%) have been using bamboo, ropes and mats to make the scaffolds to hang the fishes for drying after washing the fishes in sea water. At least this much care the fish curers have been taking to maintain the quality mostly for getting export market. 
Resource poor fish curers have been using the simple PVC sheets/ mats of palm leaves make where they spread the raw material for drying purpose. In some worst cases, it has been reported that they simply place the raw fishes on sand of the beach for drying. Saha, 1970 and Paul et al.1997, mentioned similar observation in their studies on dry fish processing.

\section{Tools/Equipments/Materials Utilized in the Khuties for Fish Drying Activity}

The perusal of the Table 13, clearly shows that 194 fish curers $(58 \%)$ of the sample used bamboo, ropes and mats as the tools for fish drying, followed by 116 fish curers (35\%) used the bamboo \& ropes and only 26 fish curers (7\%) used only mats (PVC sheets/Palm leaves make) for drying the fish.

\section{Cost of Average Raw Material}

The study (Figure1) indicates that the cost of the raw material on an average is INR 30 to 35 per $\mathrm{kg}$ which has been stated by 135 of the respondents (40\%), followed by INR 35 to 40 per $\mathrm{kg}$, by 64 respondents $(19 \%)$, INR 25 to 30 per $\mathrm{kg}$ by 58 respondents (17\%) where as maximum cost at INR 40 to 50 per $\mathrm{kg}$ of raw fish was paid by 45 respondents (13\%) and minimum cost at INR 20 to 25 per $\mathrm{kg}$ of raw fish paid by 34 respondents $(11 \%)$.

\section{Cost of Average Selling Price of End Product}

After studying the cost of selling price of end product (Figure 2), it has been observed that as many as 141 respondents (42\%) sold the end product at INR 80 to 90 per $\mathrm{kg}$, followed by INR 70 to 80 per kg by 68 fish curers (20\%), INR 90 to 100 per $\mathrm{kg}$ by 49 fish curers (15\%), INR 60 to 70 per $\mathrm{kg}$ by 40 fish curers $(12 \%)$ where as maximum price of INR 100 to 120 per $\mathrm{kg}$ was obtained by 38 fish curers $(11 \%)$. It was observed that the price varied with quality of the product.

\section{Role of Middlemen}

One of the important factors that have influenced the utilization and development of the dry fish industry of West Bengal is the socio-economic conditions of the fisher/curer community. Fishing/curing is generally considered a low profession in West Bengal and practiced mainly by the members of a number of backward communities who are largely illiterate, superstitious and extremely poor. On account of their poverty and social status, they are forced to depend on middlemen. The low standard of their living conditions, the unhygienic surroundings in which they use to deal their produce and the poor cultural status have resulted in their social isolation. The vicious circle of circumstances has crippled the fisher community both socially and economically (Bhaumik, 1989).

The study reveals that while assessing the need of middlemen in the profession of fish drying cent percent of the respondents (336 nos.) expressed apathy towards receiving the services of middlemen and expressed that it should be eliminated.

\section{Service Preferred by the Fish curers}

The study (Figure 3) reveals that out of 336 fish curers of the sample, as alternative rational for getting credit and inputs, maximum respondents $(53 \%)$ preferred the services from Co-operative Societies towards getting loans, nets, marketing facility etc, followed by Bank (38\%) and Government Agency (9\%). 
Int.J.Curr.Res.Aca.Rev.2016; 4(5): 84-100

Borrowing Habit and Borrowing Source of the Fish Curers

It has been observed that most of the fish curers borrow money to make up the deficient budget for maintenance of their livelihood or some other reasons like marriage, rituals, medical purpose or in worst occasions like addictions especially towards alcohol. The amount of debts varies with the circumstances.

Table.1 Distribution of respondents in the sample

\begin{tabular}{|l|c|l|c|c|c|}
\hline Name of District & Laying Block & \multicolumn{1}{|c|}{ Name of the Khuti } & $\begin{array}{c}\text { Sample } \\
(\mathbf{n o s})\end{array}$ & Male (nos) & Female(nos) \\
\hline South-24 Parganas & Pathar Pratima & I.Pathar Pratima Khuti & $50(14.88)$ & $47(13.99)$ & $03(0.89)$ \\
\hline South-24 Parganas & Namkhana & II. Baliara Khuti & $21(6.25)$ & $21(6.25)$ & 00 \\
\hline South-24 Parganas & Namkhana & III. Namkhana Khuti & $05(1.48)$ & $05(1.48)$ & 00 \\
\hline South-24 Parganas & Kakdwip & IV. Kakdwip Khuti & $05(1.48)$ & $05(1.48)$ & 00 \\
\hline Purba Medinipore & Contai-I & V. Junput Khuti & $145(43.15)$ & $138(41.07)$ & $07(2.08)$ \\
\hline Purba Medinipore & Contai-I & VI. Haripur Khuti & $80(23.81)$ & $80(23.81)$ & 00 \\
\hline Purba Medinipore & Ramnagar-I & VII. Jaldha Khuti & $30(8.93)$ & $29(8.64)$ & $01(0.29)$ \\
\hline
\end{tabular}

(Figures in parentheses indicate percentage)

Table.2 Age Distribution of the respondents

\begin{tabular}{|c|c|c|c|c|c|c|c|}
\hline \multirow{2}{*}{$\begin{array}{c}\text { Dimension } \\
\text { Age (Year) }\end{array}$} & \multicolumn{7}{|c|}{ Frequency of respondents in the sample } \\
\cline { 2 - 8 } & Site-I & Site-II & Site-III & Site-IV & Site-V & Site-VI & Site-VII \\
\hline $15-20$ & 0 & & & & & & \\
\hline & & & 0 & 0 & $3(0.89)$ & 0 & 0 \\
\hline $20-25$ & $2(0.58)$ & 0 & 0 & 0 & $9(2.67)$ & $2(0.58)$ & 0 \\
\hline $25-30$ & 0 & 0 & 0 & 0 & $19(5.65)$ & $4(1.19)$ & 0 \\
\hline $30-35$ & 0 & $1(0.29)$ & 0 & $1(0.29)$ & $13(3.87)$ & $9(2.68)$ & 0 \\
\hline $35-40$ & $4(1.19)$ & $5(1.48)$ & $3(0.89)$ & $3(0.89)$ & $12(3.57)$ & $9(2.68)$ & 0 \\
\hline $40-45$ & $16(4.76)$ & $6(1.78)$ & $2(0.58)$ & $1(0.29)$ & $29(8.63)$ & $11(3.27)$ & $2(0.58)$ \\
\hline $45-50$ & $16(4.76)$ & $7(2.08)$ & 0 & 0 & $30(8.93)$ & $16(4.76)$ & $13(3.87)$ \\
\hline $50-55$ & $10(2.97)$ & $2(0.58)$ & 0 & 0 & $25(7.44)$ & $8(2.38)$ & $11(3.27)$ \\
\hline $55-60$ & 0 & 0 & 0 & 0 & $3(0.89)$ & $10(2.97)$ & $4(1.19)$ \\
\hline $60-65$ & 0 & 0 & 0 & 0 & $2(0.58)$ & $10(2.97)$ & 0 \\
\hline $65-70$ & $2(0.58)$ & 0 & 0 & 0 & 0 & $1(0.29)$ & 0 \\
\hline
\end{tabular}

(Figures in parentheses indicate percentage) 
Int.J.Curr.Res.Aca.Rev.2016; 4(5): 84-100

Table.3 Distribution of caste of the respondents

\begin{tabular}{|c|c|c|c|c|c|c|c|}
\hline \multirow{2}{*}{$\begin{array}{c}\text { Dimension } \\
\text { (Caste) }\end{array}$} & \multicolumn{7}{|c|}{ Frequency of respondents in the sample } \\
\cline { 2 - 8 } & Site-I & Site-II & Site-III & Site-IV & Site-V & Site-VI & Site-VII \\
\hline Brahmin & $1(0.29)$ & 0 & 0 & 0 & $1(0.29)$ & 0 & 0 \\
\hline Kayastha & $1(0.29)$ & $2(0.58)$ & 0 & 0 & $3(0.89)$ & $2(0.58)$ & $2(0.58)$ \\
\hline Mahisya & $23(6.85)$ & $14(4.17)$ & $2(0.58)$ & $2(0.58)$ & $45(13.39)$ & $28(8.33)$ & $5(1.48)$ \\
\hline Schedule Caste & $19(5.65)$ & $5(1.48)$ & $2(0.58)$ & $2(0.58)$ & $60(17.86)$ & $42(12.5)$ & $18(5.36)$ \\
\hline Schedule Tribe & 0 & 0 & 0 & 0 & 0 & 0 & 0 \\
\hline OBC & $6(1.78)$ & 0 & $1(0.29)$ & $1(0.29)$ & $7(2.08)$ & $7(2.08)$ & $2(0.58)$ \\
\hline Muslim & 0 & 0 & 0 & 0 & $29(8.63)$ & 0 & $3(0.89)$ \\
\hline Others & 0 & 0 & 0 & 0 & 0 & $1(0.29)$ & 0 \\
\hline
\end{tabular}

Table.4 Primary Occupation

\begin{tabular}{|c|c|c|c|c|c|c|c|}
\hline \multirow{2}{*}{$\begin{array}{c}\text { Dimension } \\
\text { (Primary occupation) }\end{array}$} & \multicolumn{7}{|c|}{ Frequency of respondents in the sample } \\
\cline { 2 - 8 } & Site-I & Site-II & Site-III & Site-IV & Site-V & Site-VI & Site-VII \\
\hline Fish Drying & $50(14.88)$ & $21(6.25)$ & $5(1.48)$ & $5(1.48)$ & $129(38.39)$ & $76(22.62)$ & $30(8.93)$ \\
\hline Fishing & 0 & 0 & 0 & 0 & $12(3.57)$ & $3(0.89)$ & 0 \\
\hline Net Making \& Mending & 0 & 0 & 0 & 0 & $4(1.19)$ & $1(0.29)$ & 0 \\
\hline
\end{tabular}

Table.5 Secondary Occupation of Fish-Curers

\begin{tabular}{|c|c|c|c|c|c|c|c|}
\hline \multirow{2}{*}{$\begin{array}{c}\text { Dimension } \\
\text { (Secondary Occupation) })\end{array}$} & \multicolumn{7}{|c|}{ Frequency of respondents in the sample } \\
\cline { 2 - 8 } & Site-I & Site-II & Site-III & Site-IV & Site-V & Site-VI & Site-VII \\
\hline Fishing & $7(2.08)$ & $5(1.48)$ & 0 & 0 & $54(16.07)$ & $8(2.38)$ & 0 \\
\hline Fish sell/vendor & $31(9.23)$ & $8(2.38)$ & $3(0.89)$ & $4(1.19)$ & $20(5.95)$ & $25(7.44)$ & $6(1.78)$ \\
\hline Net making \& mending & $6(1.78)$ & $3(0.89)$ & 0 & 0 & $11(3.27)$ & $5(1.48)$ & 0 \\
\hline Labourer & $4(1.19)$ & $2(0.58)$ & 0 & 0 & $36(10.71)$ & $35(10.42)$ & $9(2.67)$ \\
\hline Other activity & $2(0.58)$ & $3(0.89)$ & $2(0.58)$ & $1(0.29)$ & $24(7.14)$ & $7(2.08)$ & $15(4.46)$ \\
\hline
\end{tabular}

Table.6 Education Level of Fish-Curers

\begin{tabular}{|c|c|c|c|c|c|c|c|}
\hline \multirow{2}{*}{$\begin{array}{c}\text { Dimension } \\
\text { Education level })\end{array}$} & \multicolumn{7}{|c|}{ Frequency of respondents in the sample } \\
\cline { 2 - 8 } & Site-I & Site-II & Site-III & Site-IV & Site-V & Site-VI & Site-VII \\
\hline Illiterate & $8(2.38)$ & $4(1.19)$ & 0 & 0 & $15(4.46)$ & $18(5.35)$ & $7(2.08)$ \\
\hline Can Read \& Write & $12(3.57)$ & 0 & 0 & 0 & $9(2.67)$ & $8(2.38)$ & $5(1.48)$ \\
\hline Primary & $27(8.03)$ & $12(3.57)$ & 0 & 0 & $58(17.26)$ & $41(12.20)$ & $4(1.19)$ \\
\hline Eight Pass & $3(0.89)$ & $1(0.29)$ & $2(0.58)$ & $1(0.29)$ & $33(9.82)$ & $6(1.78)$ & $13(3.86)$ \\
\hline Secondary & 0 & $4(1.19)$ & $3(0.89)$ & $4(1.19)$ & $26(7.74)$ & $6(1.78)$ & $1(0.29)$ \\
\hline Graduate & 0 & 0 & 0 & 0 & $4(1.19)$ & $1(0.29)$ & 0 \\
\hline
\end{tabular}


Int.J.Curr.Res.Aca.Rev.2016; 4(5): 84-100

Table.7 Family size of Fish Curers

\begin{tabular}{|c|c|c|c|c|c|c|c|}
\hline \multirow{2}{*}{$\begin{array}{c}\text { Dimension } \\
\text { Members in family) }\end{array}$} & \multicolumn{7}{|c|}{ Frequency of respondents in the sample } \\
\cline { 2 - 8 } & Site-I & Site-II & Site-III & Site-IV & Site-V & Site-VI & Site-VII \\
\hline $2-3$ & $8(2.38)$ & $4(1.19)$ & $3(0.89)$ & $4(1.19)$ & $33(9.82)$ & $14(4.17)$ & $2(0.58)$ \\
\hline $4-6$ & $19(5.65)$ & $7(2.08)$ & $2(0.58)$ & $1(0.29)$ & $58(17.26)$ & $29(8.63)$ & $14(4.17)$ \\
\hline $7-9$ & $21(6.25)$ & $10(2.97)$ & 0 & 0 & $45(13.39)$ & $31(9.23)$ & $11(3.27)$ \\
\hline $10 \&$ Above & $2(0.58)$ & 0 & 0 & 0 & $9(2.68)$ & $6(1.78)$ & $3(0.89)$ \\
\hline
\end{tabular}

Table.8 Experience in fish drying activity

\begin{tabular}{|c|c|c|c|c|c|c|c|}
\hline \multirow{2}{*}{$\begin{array}{c}\text { Dimension } \\
(\text { Years })\end{array}$} & \multicolumn{7}{|c|}{ Frequency of respondents in the sample } \\
\cline { 2 - 8 } & Site-I & Site-II & Site-III & Site-IV & Site-V & Site-VI & Site-VII \\
\hline $1-5$ & $2(0.58)$ & $1(0.29)$ & 0 & 0 & $17(5.05)$ & $7(2.08)$ & 0 \\
\hline $6-10$ & $4(1.19)$ & $6(1.78)$ & $3(0.89)$ & $4(1.19)$ & $38(11.31)$ & $13(3.86)$ & $1(0.29)$ \\
\hline $11-15$ & $23(6.84)$ & $11(3.27)$ & $2(0.58)$ & $1(0.29)$ & $66(19.64)$ & $16(4.76)$ & $13(3.86)$ \\
\hline $16-20$ & $15(4.46)$ & $3(0.89)$ & 0 & 0 & $17(5.05)$ & $15(4.46)$ & $11(3.27)$ \\
\hline $21-25$ & $4(1.19)$ & 0 & 0 & 0 & $5(1.48)$ & $13(3.86)$ & $4(1.19)$ \\
\hline $26-30$ & $2(0.58)$ & 0 & 0 & 0 & $2(0.58)$ & $7(2.08)$ & $1(0.29)$ \\
\hline $31-35$ & 0 & 0 & 0 & 0 & 0 & $5(1.48)$ & 0 \\
\hline $35-40$ & 0 & 0 & 0 & 0 & 0 & $4(1.19)$ & 0 \\
\hline
\end{tabular}

Table.9 House in possession of the Fish Curers

\begin{tabular}{|c|c|c|c|c|c|c|c|}
\hline \multirow{2}{*}{$\begin{array}{c}\text { Dimension } \\
\text { (Type of Houses) }\end{array}$} & \multicolumn{7}{|c|}{ Frequency in the sample } \\
\cline { 2 - 8 } & Site-I & Site-II & Site-III & Site-IV & Site-V & Site-VI & Site-VII \\
\hline Pucca (building) & $22(6.55)$ & $8(2.38)$ & $3(0.89)$ & $4(1.19)$ & $40(11.90)$ & $24(7.14)$ & $6(1.78)$ \\
\hline Tin/Tile shed & $24(7.15)$ & $10(2.97)$ & $2(0.58)$ & $1(0.29)$ & $98(29.16)$ & $47(13.98)$ & $19(5.66)$ \\
\hline Thatched hut & $4(1.19)$ & $3(0.89)$ & 0 & 0 & $7(2.08)$ & $9(2.67)$ & $5(1.48)$ \\
\hline
\end{tabular}

Table.10 Gadgets in possession of the Fish-Curers

\begin{tabular}{|c|c|c|c|c|c|c|c|}
\hline \multirow{2}{*}{$\begin{array}{c}\text { Dimension } \\
\text { (Gadgets) }\end{array}$} & \multicolumn{7}{|c|}{ Frequency in the sample } \\
\cline { 2 - 8 } & Site-I & Site-II & Site-III & Site-IV & Site-V & Site-VI & Site-VII \\
\hline Radio set & $35(10.42)$ & $6(1.78)$ & $2(0.58)$ & $1(0.29)$ & $47(13.98)$ & $12(3.57)$ & $5(1.48)$ \\
\hline Wrist Watch & $16(4.76)$ & $8(2.38)$ & $1(0.29)$ & $2(0.58)$ & $10(2.97)$ & $8(2.38)$ & $4(1.19)$ \\
\hline Television set & $37(11.01)$ & $17(5.05)$ & $5(1.48)$ & $4(1.19)$ & $77(22.92)$ & $34(10.11)$ & $18(5.35)$ \\
\hline Mobile set & $42(12.5)$ & $18(5.35)$ & $5(1.48)$ & $5(1.48)$ & $125(37.20)$ & $68(20.24)$ & $25(7.44)$ \\
\hline Bi-cycle & $32(9.52)$ & $20(5.95)$ & $3(0.89)$ & $2(0.58)$ & $132(39.28)$ & $72(21.42)$ & $26(7.74)$ \\
\hline Motor-cycle & $26(7.74)$ & $11(3.27)$ & $3(0.89)$ & $4(1.19)$ & $47(13.98)$ & $25(7.44)$ & $14(4.17)$ \\
\hline
\end{tabular}


Int.J.Curr.Res.Aca.Rev.2016; 4(5): 84-100

Table.11 Income of the fish curers during season

\begin{tabular}{|c|c|c|c|c|c|c|c|}
\hline \multirow{2}{*}{$\begin{array}{c}\text { Dimension } \\
\text { (ncome in INR } * \text { ) }\end{array}$} & \multicolumn{7}{|c|}{ Frequency of respondents in the sample } \\
\cline { 2 - 8 } & Site-I & Site-II & Site-III & Site-IV & Site-V & Site-VI & Site-VII \\
\hline $3000-4000$ & $3(0.89)$ & $2(0.58)$ & 0 & 0 & $13(3.86)$ & $9(2.67)$ & $4(1.19)$ \\
\hline $4000-5000$ & $6(1.78)$ & $4(1.19)$ & 0 & 0 & $17(5.05)$ & $11(3.27)$ & $7(2.08)$ \\
\hline $5000-6000$ & $12(3.57)$ & $7(2.08)$ & 0 & 0 & $22(6.54)$ & $14(4.17)$ & $8(2.38)$ \\
\hline $6000-8000$ & $21(6.25)$ & $5(1.48)$ & $1(0.29)$ & 0 & $56(16.67)$ & $26(7.74)$ & $5(1.48)$ \\
\hline $8000-10,000$ & $5(1.48)$ & $2(0.58)$ & $2(0.58)$ & $2(0.58)$ & $25(7.44)$ & $13(3.86)$ & $4(1.19)$ \\
\hline Above 10,000 & $3(0.89)$ & $1(0.29)$ & $2(0.58)$ & $3(0.89)$ & $12(3.57)$ & $7(2.08)$ & $2(0.58)$ \\
\hline
\end{tabular}

Table.12 Income of fish curers during off-season

\begin{tabular}{|c|c|c|c|c|c|c|c|}
\hline \multirow{2}{*}{$\begin{array}{c}\text { Dimension } \\
\text { (Income in INR) }\end{array}$} & \multicolumn{7}{|c|}{ Frequency of respondents in the sample } \\
\cline { 2 - 8 } & Site-I & Site-II & Site-III & Site-IV & Site-V & Site-VI & Site-VII \\
\hline $2000-3000$ & $5(1.48)$ & $5(1.48)$ & 0 & 0 & $18(5.35)$ & $13(3.86)$ & $5(1.48)$ \\
\hline $3000-3500$ & $6(1.78)$ & $4(1.19)$ & $1(0.29)$ & $1(0.29)$ & $16(4.76)$ & $11(3.27)$ & $9(2.67)$ \\
\hline $3500-4000$ & $11(3.27)$ & $3(0.89)$ & $1(0.29)$ & $2(0.58)$ & $44(13.1)$ & $10(2.97)$ & $6(1.78)$ \\
\hline $4000-4500$ & $16(4.76)$ & $5(1.48)$ & 0 & 0 & $30(8.92)$ & $27(8.03)$ & $5(1.48)$ \\
\hline $4500-5000$ & $7(2.08)$ & $3(0.89)$ & $2(0.58)$ & $1(0.29)$ & $25(7.44)$ & $13(3.86)$ & $3(0.89)$ \\
\hline Above 5000 & $5(1.48)$ & $1(0.29)$ & $1(0.29)$ & $1(0.29)$ & $12(3.57)$ & $6(1.78)$ & $2(0.58)$ \\
\hline
\end{tabular}

Table.13 Tools/ equipments used in the Khuties for fish drying

\begin{tabular}{|c|c|c|c|c|c|c|c|}
\hline \multirow{2}{*}{$\begin{array}{c}\text { Dimension } \\
\text { (Tool/equipments) }\end{array}$} & \multicolumn{7}{|c|}{ Frequency of respondents in the sample } \\
\cline { 2 - 8 } & Site-I & Site-II & Site-III & Site-IV & Site-V & Site-VI & Site-VII \\
\hline Bamboo, Ropes \& Mats & $20(5.95)$ & $5(1.48)$ & $5(1.48)$ & $5(1.48)$ & $88(29.19)$ & $54(16.1)$ & $17(5.05)$ \\
\hline Bamboo \& Ropes & $26(7.73)$ & $13(3.86)$ & 0 & 0 & $48(14.28)$ & $20(5.95)$ & $9(2.67)$ \\
\hline Mats & $4(1.19)$ & $3(0.89)$ & 0 & 0 & $9(2.67)$ & $6(1.78)$ & $4(1.19)$ \\
\hline
\end{tabular}

Table.14 Repayment of loan by the Fish curers

\begin{tabular}{|c|c|c|c|c|c|c|c|}
\hline \multirow{2}{*}{$\begin{array}{c}\text { Dimension } \\
\text { (Repayment of loan) }\end{array}$} & \multicolumn{7}{|c|}{ Frequency of respondents in the sample } \\
\cline { 2 - 8 } & Site-I & Site-II & Site-III & Site-IV & Site-V & Site-VI & Site-VII \\
\hline Regular & $42(12.5)$ & $17(5.1)$ & $4(1.19)$ & $5(1.48)$ & $129(38.4)$ & $74(22.02)$ & $27(8.03)$ \\
\hline Irregular & $8(2.38)$ & $4(1.19)$ & $1(0.29)$ & 0 & $16(4.76)$ & $6(1.78)$ & $3(0.89)$ \\
\hline
\end{tabular}


Int.J.Curr.Res.Aca.Rev.2016; 4(5): 84-100

Figure.1 Cost of average raw material (in INR)

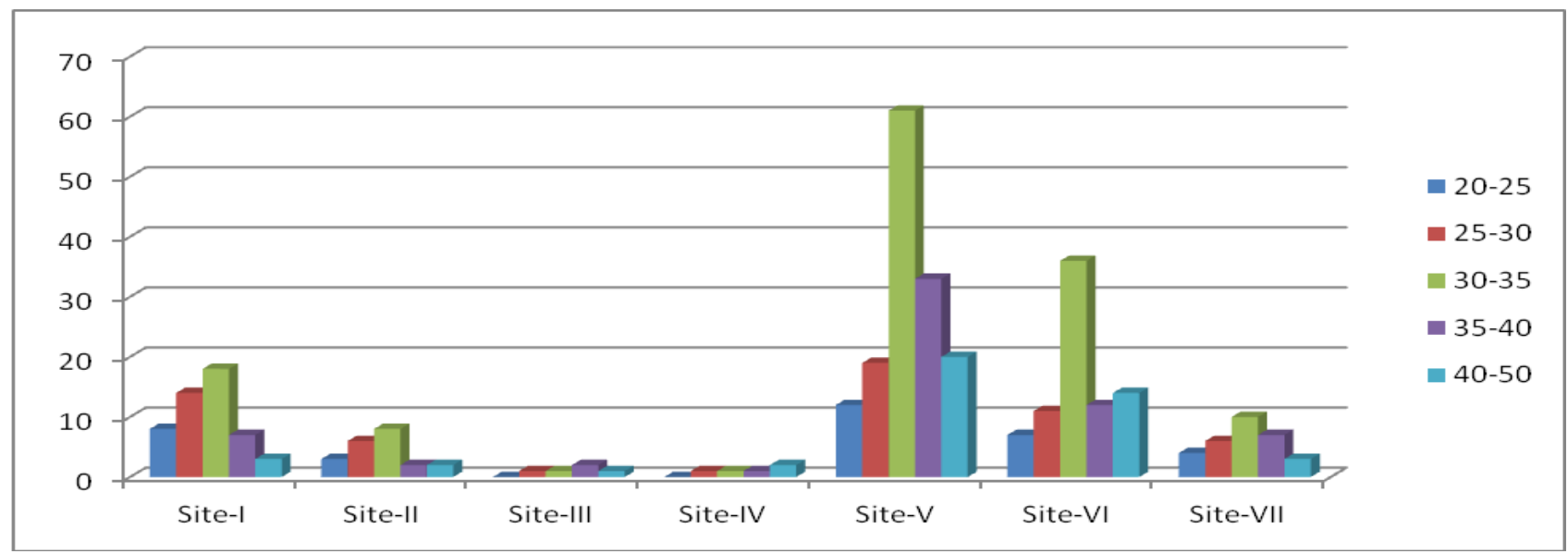

Figure.2 Cost of average selling price (in INR) of end product

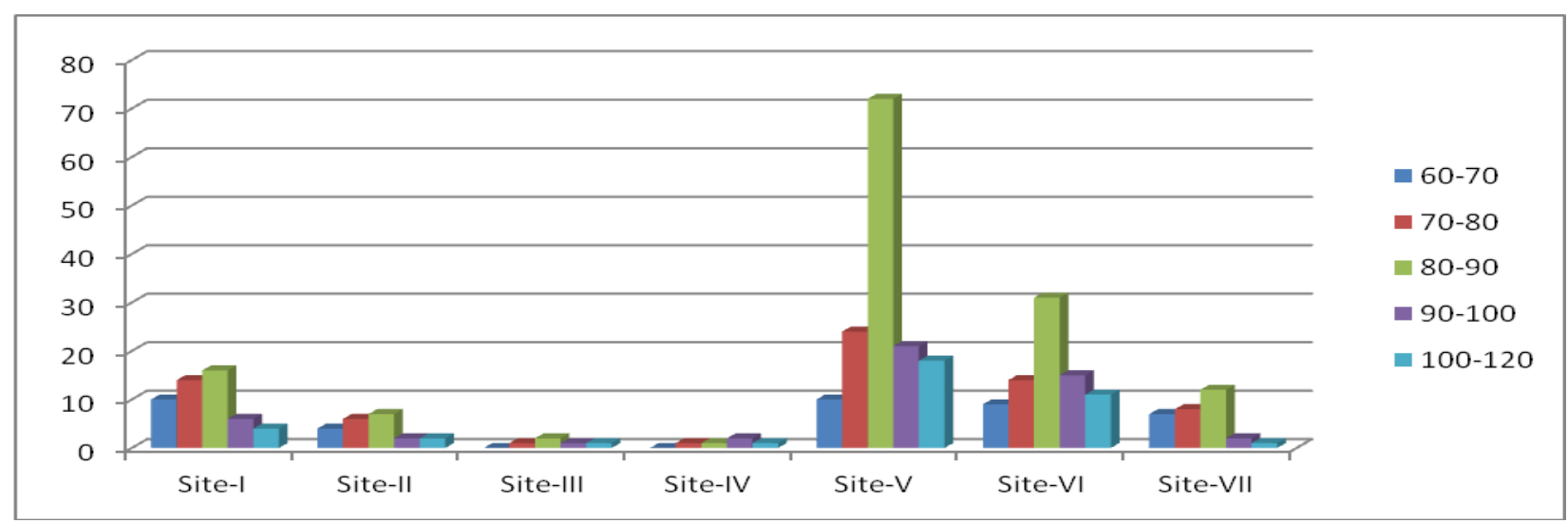

Figure.3 Service desired by the fish curers

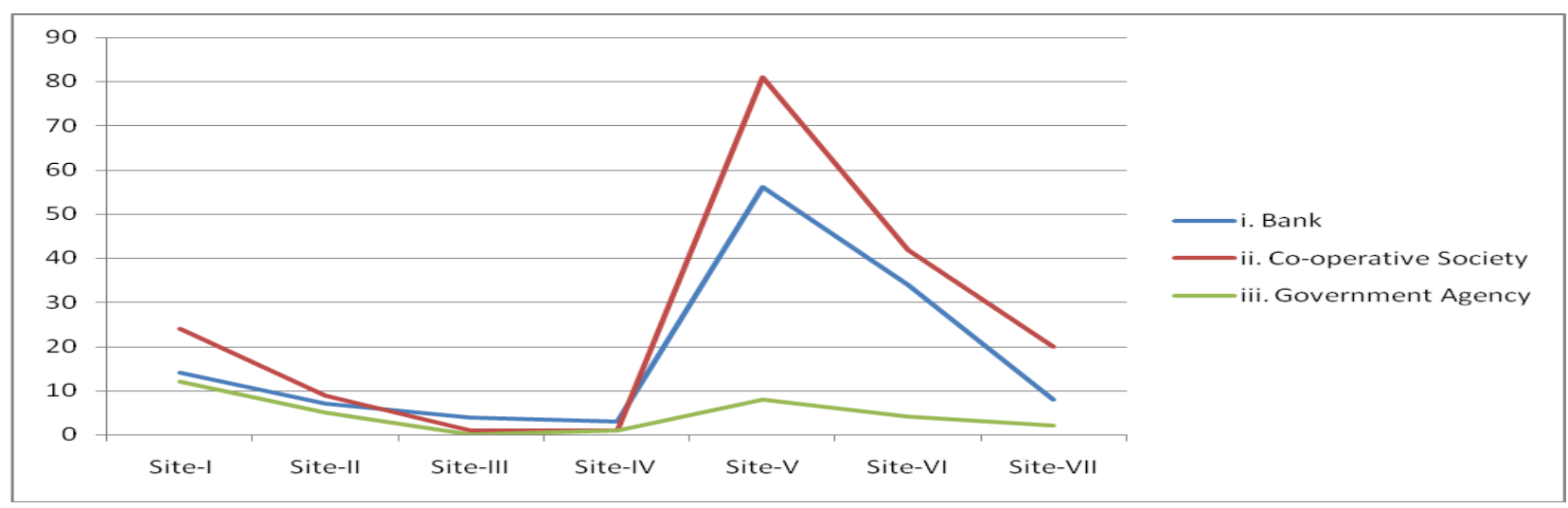


Int.J.Curr.Res.Aca.Rev.2016; 4(5): 84-100

Figure.4 Borrowing habit of fish curers

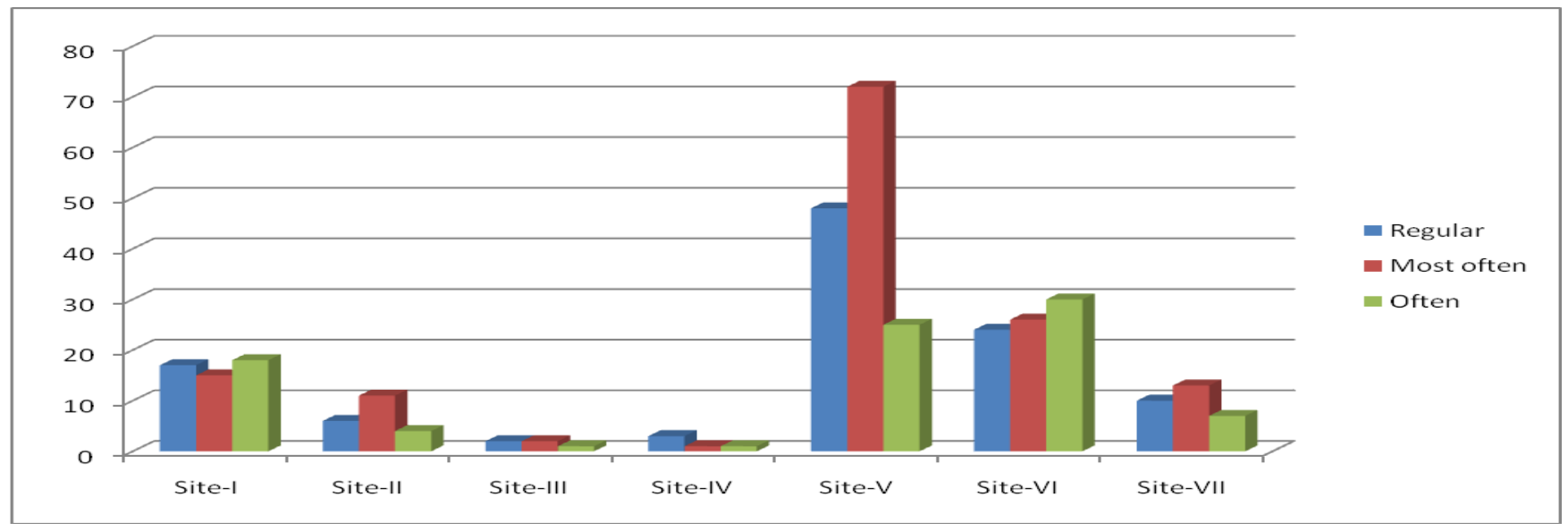

Figure.5 Extent of indebtedness (in INR) of fish curers

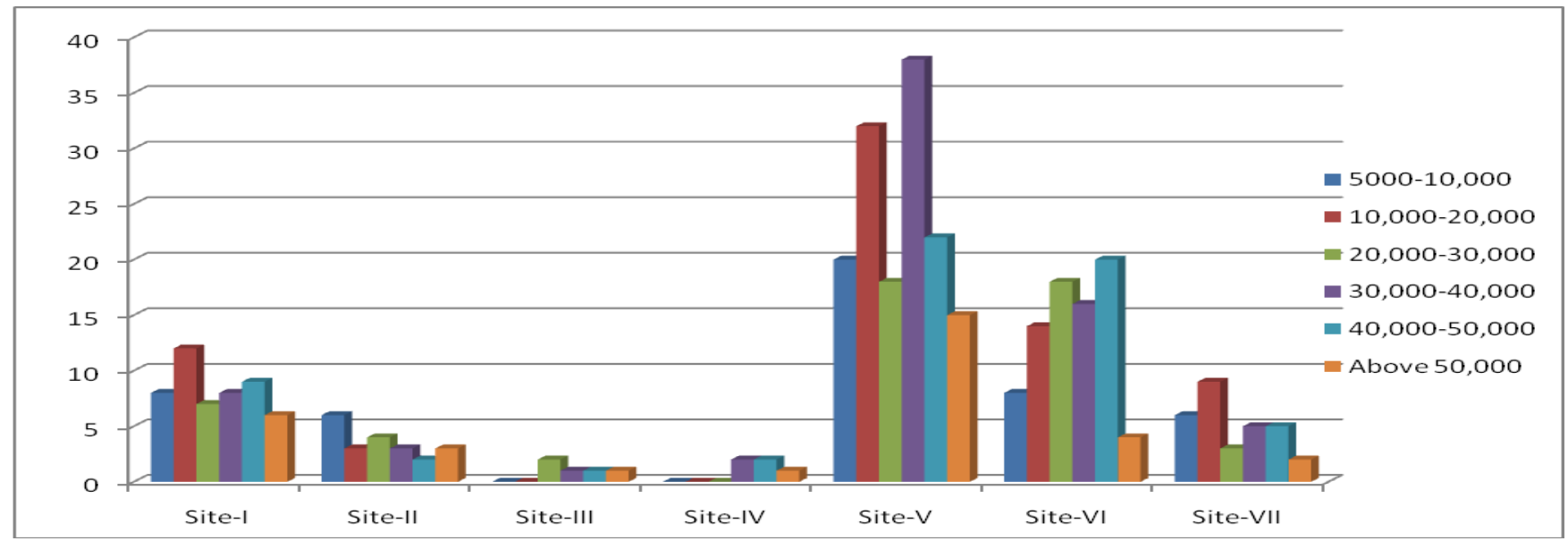

Figure.6 Borrowing source of Fish curers

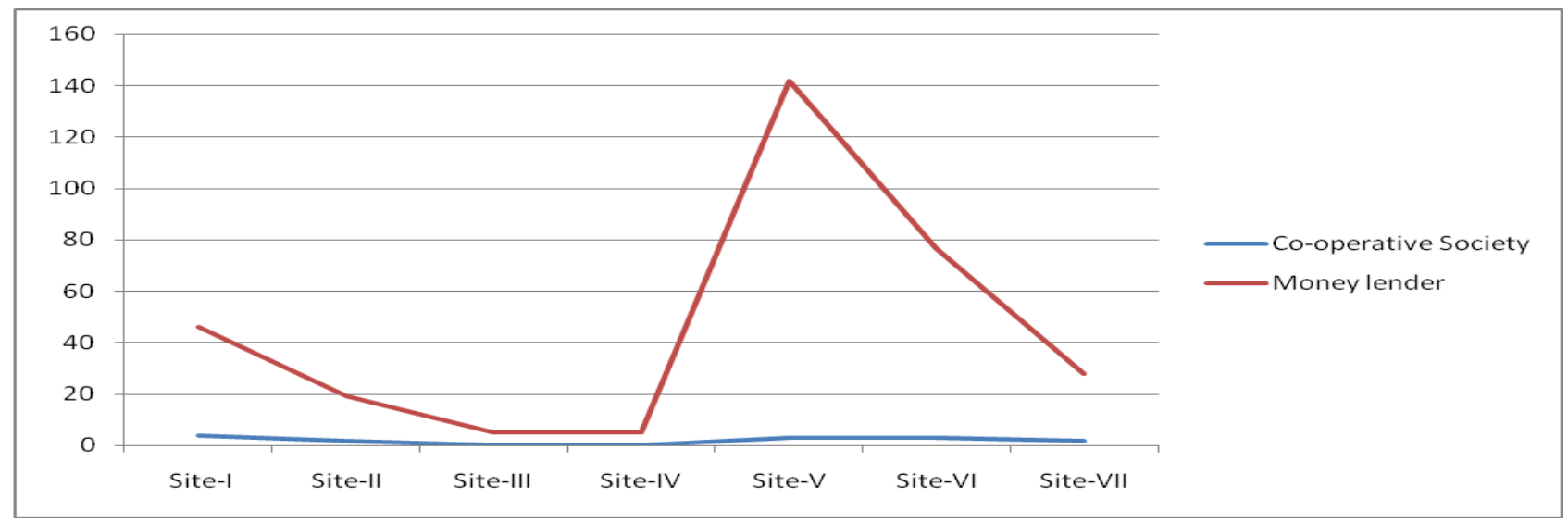




\section{Borrowing Habit}

The study (Figure 4) indicates that the fish curers basically possess a habit of borrowing money. The study reveals that out of 336 respondents of the sample, a large section of the fish curers (40\%) borrow money 'Most often' followed by (35\%) of the fish curers borrow money on 'Regular' basis and 25\% of the fish curers borrow money 'Often'. Study also reveals that $89 \%$ of them repay the loan on regular basis.

\section{Extent of Indebtedness of fish curers}

Many studies reveal that most of the fishers/curers are involved in indebtedness owing to various reasons. Indebtedness has been observed to become chronic in the life of the fisher /curer communities. The extent of expenditure on household necessitates about 70 to $80 \%$ of their income towards food only that too, minimum requirement of rice, flour, pulses, oil, spices, potato and onion. For supporting their livelihood, the fishers/fish curers frequently borrow money from various sources.

The study further (Figure 6) reveals that the fish curers borrowed money from different sources and the amount varied between INR $5000 /-$ and $>50,000$. It has been observed that 73 fish curers $(22 \%)$ borrowed money @ INR 30,000 to 40,000, followed by INR 10,000 to 20,000 by 70 respondents $(21 \%)$, INR 40,000 to 50,000 by 61 respondents (18\%), INR 20,000 to 30,000 by 52 respondents $(15 \%)$ where as minimum amount of INR 5000 to 10,000 was borrowed by 48 respondents (14\%) and the maximum amount of INR 50,000 and above, was borrowed by 32 respondents $(10 \%)$.

\section{Borrowing Source of Fish Curers}

The study (Figure 7) shows that maximum number of the respondents $(96 \%)$ of the sample borrowed money from the money lenders, followed by from the Co-operative Society (4\%). The most of the fish curers owing to drudgery, for immediate solution, take loans from the money lenders who are easily accessible. Such money lenders lend money any amount to the curers in anticipation that the recipients will sell the whole end products to them. Thus, the fish curers are compelled to sell their products to the money lenders in comparatively lesser market price.

\section{Repayment of Loan by the Fish curers}

The data obtained (Table15) reveals that maximum number of fish curers (298) as $89 \%$ are 'regular' towards repayment of their loan followed by 38 fish curers $(11 \%)$ are 'irregular' to repayment of their loan.

\section{Conclusion}

The dry fish industry in West Bengal does not function in an organised manner. Majority of the fish curers procure raw material from the landing centres where the fishing vessels land every day. A few fish curers earn more profit procuring raw material through fishing in the sea. Some resource poor fish curers make hunt in search of discarded fishes which are often thrown from the trawlers and they collect those to undertake fish drying operation. But they are crippled with many problems especially pecuniary hardship where they come under the grip of middlemen/money lenders. Governments, with their finite resources, cannot solve all these problems. Local communities will need to take more responsibility for solving local problems. In order to overcome this, however, communities must be empowered and resources provided to make decisions locally and to take actions that meet local opportunities and problems. The assistance 
and support of government will still be needed to achieve these results, although the role and responsibilities of government will also need to change.

\section{References}

Balasubramaniam, S., Kaul, P.N. 1982. Adoption Of Improved Fish Curring Practices. In :45-50,Indian Journal Of Extension Education. Vol. XVIII. Nos.3 And 4 December, 1982.

Bhaumik Utpal. 1989. CIFRI bull., 106:12710.

Bhaumik, Utpal, Pandit, P.K. 1991a. Socio-economic status of fisherman in some beels Of West Bengal. Environ. Ecol., 9(3): 600-603.

Bhaumik, Utpal, Pandit, P.K., Chaterjee, J.G. 1990. Participation of fisherwomen in inland Fisheries Activities. Per problems And Measures. Environ. Ecol., 8(2): 71316.

Bhaumik, Utpal, I.C., Mittal, P., Das, T., Paria. 2006. Socio-Economic Status of fishers of two floodplain wetlands of West Bengal;. Environ. Ecol., 24(2): 404-411.

Biswas, Ashish. 1991. Studies on some socio-economic aspects of fisherman of Sundarbans Dissertation. M.F. Sc. IFTC (CIFE-Deemed university), Barrackpore :59p.

Das, Madhumita, Rohit, Prathibha, Maheswarudu, G., Dash, Biswajit, Ramana, P.V. 2013. An overview of dry fish landings and trade at Visakhapatnam Fishing Harbour, Regional Centre of CMFRI, Visakhapatnam, Marine Fisheries Information Service $\mathrm{T} \& \mathrm{E}$ Ser. No. 125, 2013; pp. 3-7.

FAO. 2012. 'Global Aquaculture Production Statistics for the year 2011'. Fishery/topic/16140/en.
Faruque, M.O., Nazrul, K.M.S., Tonny, U.S., Islam, K.R., Dey, S.C., Mona, S.J., Saha, D. 2012. 'Status of an ideal dry fish market of Bangladesh: A study on Asadganj dry fish market, Chittagong'. Int. J. Life Sc. Bt. Pharm. Res., Vol. 1, No. 3, July 2012.

Ghorai, Sudipta Kumar, Bera, Santosh Kumar, Jana, Debanjan, Mishra, Somnath. 2014. Status of the largest dry fish market of East India: A study on Egra Regulated Dry Fish Market, Egra, Purba Medinipur, West Bengal, Int. J. Curr. Res. Acad. Rev., ISSN: 2347-3215 Vol. 2 Number 5 (May 2014) pp. 54-65.

Goswami, M., Satbiadbas, R., Goswami, U.C. 2002. 'Market flow, price structure and fish marketing system in Assam- A case study'. In: Processdings of National Conference on Fisheries Economics, Extension and Management, 2002, CIFE; Mumbai.

Govindam, T.K. 1985. Handling, Preservation and Transportation of Fresh Fish. In :44-76. Fish Processing Technology. Oxford and IBH Publishing Co. Pvt. Ltd.

Haque. A. 1981. Study of some factors related to the adoption of recommended species of fish in composite fish culture, unpublished.

MPEDA. 2013. ' $19^{\text {th }}$ India International Seafood Show at Chennai Trade Centre, Chennai'. PRESS RELEASE- 24 JUNE, 2013.

Nowsad, A.K.M.A. 2007. Participatory Training of Trainers: A New Approach Applied in Fish Processing, Bengal Com-print, 68/5, Green Road, Dhaka, Bangladesh, 328.

Paul, S., Mitra, P.M., De, D.K., Sen, H.K., Mandal, N.C., Singh, P. 1997. Winter migratory bagnet fishery of the 
Hooghly estuary- an -economic evaluation. (Ed). CIFRI-Bull. No.76. Ind.P.2.

Saha, K.C. 1970. Sun-dried fish trade and other fish by-products. In : Fisheries of West Bengal, Department of Fisheries, Government of West Bengal; 87-89.

Samanta Chanchal, Bhaumik Utpal, Patra Bidhan Chandra. 2016. Perspectives of the Dry Fish Indu-stry in Coastal Areas of West Ben-gal, India, Int. J. Curr. Res. Aca. Rev., 4(3): 63-75.
Sinha, M., Sugnan, V.V., Chandra, K., Jha, B.C., Katiha, P.K., Singh, M.P., Biawas, D.K. 2000. Final report on monitoring of the Inland fisheries component of the world Bank assisted fish and shrimp culture project. CIFRI : $175 \mathrm{p}$.

Srivastava, U.K. 1985. Inland fish marketing in india. Vol.374 IIM Ahmedabad. Concept publishing Co. New Dehli.

Sugunan, V.V., Bhattacharya, B.K. 2000. Ecology and fisheries of beels in Assam CIFRI Bull.104:65p.

\section{How to cite this article:}

Chanchal Samanta, Utpal Bhaumik and Bidhan Chandra Patra. 2016. Socio-Economic Status of the Fish Curers of the Dry Fish Industry of the Coastal Areas of West Bengal, India. Int.J.Curr.Res.Aca.Rev.4(5): 84-100. doi: http://dx.doi.org/10.20546/ijcrar.2016.405.009 